\title{
Pheochromocytoma and Paraganglioma Pathologic TNM Finding v8
}

National Cancer Institute

\section{Source}

National Cancer Institute. Pheochromocytoma and Paraganglioma Pathologic TNM

Finding v8. NCI Thesaurus. Code C141113.

A pathologic finding about one or more characteristics of pheochromocytoma and paraganglioma, following the rules of the TNM AJCC v8 classification system. 